УДК 582.31:581.524 (571.65)

\title{
СОСУДИСТЫЕ РАСТЕНИЯ ОТВАЛОВ ЗОЛОТОДОБЫЧИ МАГАДАНСКОЙ ОБЛАСТИ
}

\author{
Андриянова Е. А., Докучаева В. Б. \\ ФГБУН Институт биологических проблем Севера ДВО РАН, г. Магадан \\ E-mail: elena.a.andriyanova@gmail.com
}

\begin{abstract}
По оригинальным и литературным данным составлен список сосудистых растений, отмеченных к настоящему времени на землях, нарушенных в результате добычи золота в континентальной части Магаданской области. Всего на отвалах золотодобычи в Тенькинском, Ягоднинском и Сусуманском районах области произрастает 241 вид сосудистых растений. Спектр ведущих семейств флоры техногенных ландшафтов соответствует таковому для бореальных флор. На обследованных отвалах встречаются эндемичные (Oxytropis vasskovskyi) и редкие (Scirpus tabernaemontani, Salix pyrolifolia) виды. Выявлены 44 вида растений, наиболее обычных на отвалах, большинство из них могут быть рекомендованы для рекультивации нарушенных золотодобычей ландшафтов в Магаданской области.
\end{abstract}

Ключевые слова: флора, нарушенные территории, самозарастание, Магаданская область.

DOI: $10.34078 / 1814-0998-2020-4-70-81$

Общая площадь земель в Магаданской области, нарушенных в результате золотодобычи, на сегодня составляет, по разным источникам, от

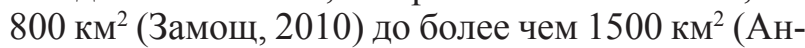
дреев, 2013). Относительно всей площади территории области (462 тыс. км²) это немного. Однако основная часть нарушенных земель находится в долинах рек и ручьев, где сосредоточены самые ценные земли и продуктивные растительные сообщества с высоким видовым разнообразием. Добыча золота в Магаданской области ведется с 1930-х гг. В настоящее время большая часть отвалов золотодобычи не рекультивирована, лишь иногда проводилась их первичная планировка (Замощ, 2010) и в отдельных случаях - работы по формированию первичного почвенного слоя и растительного покрова (Тихменев, Тихменев, 2012).

В условиях Севера затраты на проведение рекультивации, как правило, не окупаются. Наибольшее значение имеет природоохранный аспект восстановления нарушенных земель снижение отрицательного влияния на окружающую среду и формирование эстетической привлекательности ландшафта. Это может быть достигнуто не только в результате активной рекультивации нарушенных земель, но и при их естественном зарастании (Замощ, 2010; Капель-

(C) Андриянова Е. А., Докучаева В. Б., 2020 кина и др., 2014). Информация о флоре нарушенных земель и успешности выживания отдельных видов растений позволит оптимально спланировать мероприятия по рекультивации.

В сопредельных с Магаданской областью регионах флора и растительность нарушенных земель наиболее подробно изучены на юге Дальнего Востока (Осипов и др., 2008; Борисова, Старченко, 2009; Ивакина и др., 2013; Ивакина, Осипов, 2016; и др.). Имеются работы по некоторым районам Якутии (Захарова и др., 2010; Миронова, 2016) и Чукотки (Сумина, Яцкевич, 1990). По Магаданской области данных по флоре нарушенных земель немного. А. В. Беликович (2001) по данным полевых работ 1987-1989 гг. указывает 156 видов растений на отвалах золотодобычи в окрестностях г. Сусуман. Ранее для отвалов в этом районе отмечалось 75 видов (Поспелова, Тишков, 1973). Анализ флоры отвалов в окрестностях пос. Транспортный проведен Д. С. Лысенко (2006). В некоторых публикациях упоминаются отдельные виды растений, заселяющие отвалы золотодобычи Магаданской области (Подковыркина, 1989; Пугачев, Тихменев, 2007; Тихменев, 2010).

Задачи данной работы - по результатам собственных полевых работ и литературным данным составить список видов сосудистых растений, произрастающих на отвалах россыпной золотодобычи в Магаданской области, а также выявить наиболее распространенные виды. 


\section{МАТЕРИАЛ И МЕТОДЫ}

Исходными материалами для этой работы послужили результаты собственных исследований и литературные источники. Полевые изыскания проводились нами в течение 4 полевых сезонов. В 2002 г. обследована долина р. Ат-Юрях в окрестностях пос. Ягодное Ягоднинского района. Основной материал собран в 2008 и 2012 г. в долине р. Омчак ниже пос. Омчак на протяжении 12 км и в нижних частях долин ее притоков. В 2008 г. часть описаний в долине р. Омчак сделана Д. С. Лысенко, им же определены виды родов Poa, Elymus, Puccinellia и Scirpus, собранные в 2008 г. На руч. Родионовский (приток р. Нелькоба) работы проводились в 2012 и 2019 г.

Крупные по площади фитоценозы на отвалах описывались на пробных площадках (ПП) размерами $10 \times 10$ м. В долине р. Омчак было заложено и описано 26 таких ПП, в долине р. Ат-Юрях и ее притоков - 12, в долине руч. Родионовский -2 ПП. Часть описаний выполнена в естественных границах сообществ. В местах проведения геологоразведочных буровых работ в верховьях руч. Родионовский были заложены 62 ПП размерами $4 \times 4 \mathrm{M}$.

Участие видов в сложении сообществ оценивали по 8-балльной шкале обилия-встречаемости (Миркин и др., 2001). Во время маршрутов фиксировались все встреченные на отвалах виды, в том числе не отмеченные в границах ПП.

Геоботанические описания в окрестностях пос. Омчак и Ягодное проводили на отвалах золотодобычи старше 15-20 лет, в долине руч. Родионовский - старше 7-20 лет. Большая часть ПП заложена на вскрышных отвалах, гранулометрический состав которых близок к естественному составу аллювиальных отложений, лишь 2 ПП в окрестностях пос. Омчак - на илоотстойниках.

По результатам наблюдений составлены флористические списки для каждого изученного участка, а также общий список видов, отмеченных на отвалах золотодобычи Магаданской области, с учетом литературных данных.

Названия растений приводятся по сводке «Флора и растительность Магаданской области» (2010). Гербарные образцы хранятся в гербарии ИБПС ДВО РАН (МАG).

Природные условия района работ

Континентальная часть Магаданской области, где проводились все работы, представляет собой среднегорье с небольшими абсолютными высотами возвышенностей (до 1200-1500 м, изредка до 2000 м). Данный район относится к области сплошного распространения многолетнемерзлых пород, лишь под руслами рек отмечаются таликовые зоны.

Согласно флористическому районированию Б. А. Юрцева (1974), изучаемый район отно- сится к Северо-Охотской провинции ВосточноСибирской подобласти Бореальной флористической области.

Основной закономерностью организации растительного покрова исследованной территории является высотная поясность. В нижнем (лесном) поясе обычны пойменные тополево-чозениевые леса и ивняки, лиственничники террас и нижних частей склонов. В подгольцовом поясе преобладают сообщества крупных стлаников (в основном Pinus pumila), лиственничные редколесья, кустарниковые и кустарничковые тундры. Выше расположен гольцовый пояс с кустарничковолишайниковыми тундрами и разреженными группировками арктоальпийских травянистых петрофитов. Снизу вверх возрастает относительная площадь незадернованных каменистых поверхностей. Границы высотных поясов нечеткие, извилистые; высотный профиль растительности меняется в зависимости от экспозиции склона, распределения мерзлоты и т. п. Вследствие этого нарушенные земли граничат с разнообразными растительными сообществами, что делает возможным заселение на отвалы зачатков растений разных эколого-ценотических групп.

В ходе открытой разработки месторождений золота образуются как сильно нарушенные участки (собственно отвалы золотодобычи), так и менее нарушенные (места проведения геологоразведочных работ, дороги).

В районах наших исследований преобладают отвалы дражной золотодобычи. Техногенный ландшафт, образовавшийся после прохождения драги, состоит из гряд галечных отвалов, разделенных понижениями (дражными пазухами), обычно заполненными водой. Комплекс гряд и пазух окружен отвалами вскрыши. Местами отдельные участки долины перекрыты дамбами и превращены в пруды-илоотстойники.

Благодаря сильной расчлененности рельефа и обилию техногенных водоемов в данном ландшафте наблюдается высокое разнообразие местообитаний. Это делает возможным зарастание отвалов золотодобычи видами различной экологической приуроченности.

Долина р. Омчак между пос. Омчак и Транспортный в настоящее время представляет собой антропогенно измененный ландшафт с полностью уничтоженными естественными растительными сообществами. Слабонарушенные пойменные леса сохранились лишь выше пос. Омчак и ниже пос. Транспортный. Протяженность нарушенной части долины р. Омчак составляет около 25 км, ширина - от 0.7 до 1.7 км. Добыча золота в долине р. Омчак началась в 1940-х гг. Точный возраст конкретных участков отвалов определить невозможно, так как нередко производилась повторная промывка грунтов. Долина р. Омчак 
занята мозаично расположенными отвалами разного возраста.

Долина р. Ат-Юрях в окрестностях пос. Ягодное также представляет собой полностью измененный ландшафт с преобладанием дражных отвалов разного возраста - 30-40-летние отвалы перемежаются более молодыми.

Небольшая по протяженности долина руч. Родионовский нарушена неравномерно. Геологоразведочные работы здесь были начаты в 1944 г., разработку золотоносных россыпей вели гидравлическим способом. Верхняя часть долины руч. Родионовский несет значительные нарушения, в нижней ее части сильно нарушенные участки разного возраста чередуются со слабонарушенными.

Места проведения полевых работ показаны на рисунке.

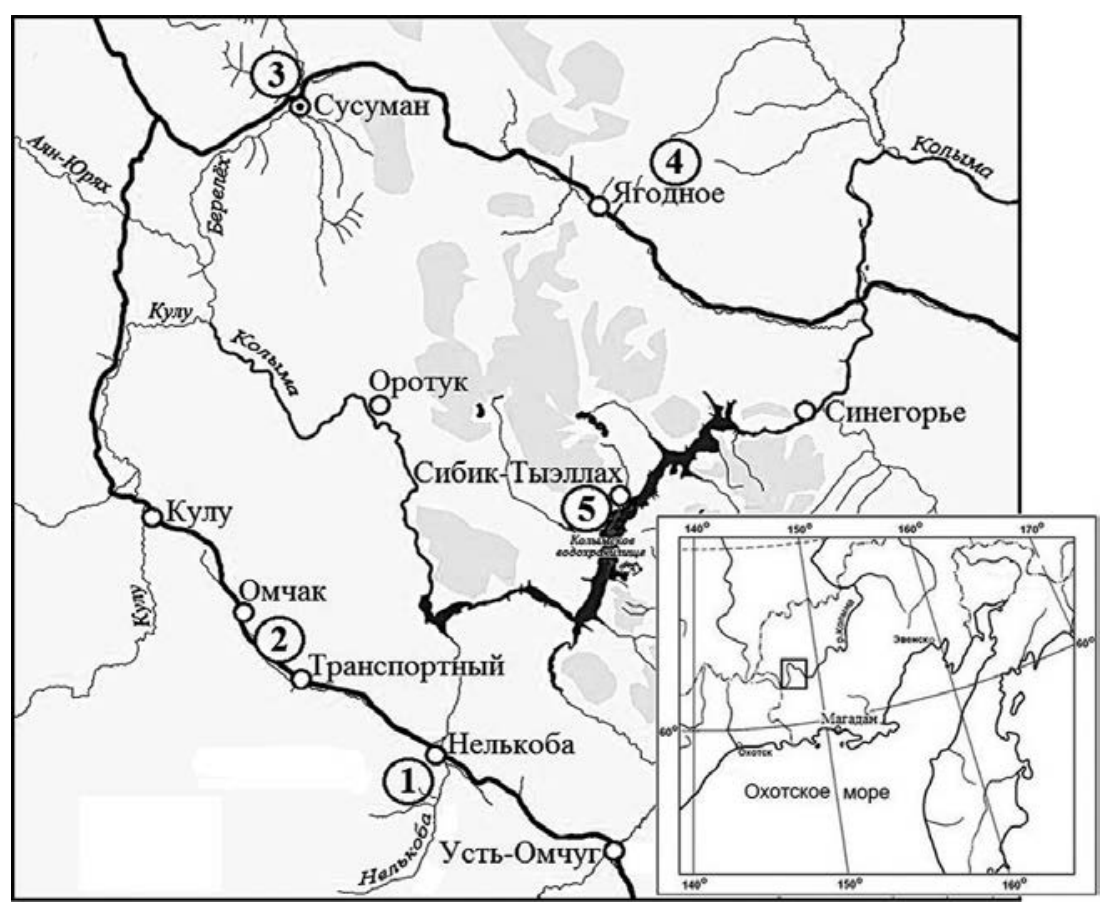

Рисунок. Карта бассейна верховий Колымы. Цифрами обозначены участки проведения работ: 1 - руч. Родионовский; 2 - Омчак / Транспортный; 3 - Сусуман; 4 - Ягодное; 5 - Сибик-Тыэллах. На врезке: расположение территории на обзорной карте

Figure. Map of the Upper Kolyma River basin. Numbers indicate the sites of work: 1 - Rodionovskiy creek; 2 - Omchak / Transportniy; 3 - Susuman; 4 - Yagodnoye; 5 - Sibik-Tyellakh. Inset: the area location on the sketch map

Абсолютные высоты изученных участков в окрестностях пос. Омчак составляют 740-800 м, в окрестностях пос. Транспортный - 660-680 м, в окрестностях пос. Ягодное - 500-600 м, а в верховьях руч. Родионовский - 700-1100 м.

\section{РЕЗУЛЬТАТЫ}

На обследованных отвалах золотодобычи Магаданской области нами обнаружено 148 видов сосудистых растений (табл. 1). В таблице пока- зано обилие видов на каждом из изученных нами участков. Для сравнения указано, приводились ли данные виды в списках других авторов (Беликович, 2001; Лысенко, 2006).

Общее количество видов, отмеченных на нарушенных золотодобычей землях в бассейне Верхней Колымы с учетом литературных данных, составляет 241 вид из 38 семейств и 118 родов.

Полнота видовых списков рассматриваемых участков не одинакова. Обследование долины руч. Родионовский проводилось в сентябре, когда определение многих видов затруднено (например, виды рода Роа). В окрестностях пос. Ягодное полевые работы были кратковременными. Эти списки используются нами как вспомогательные. Один вид (Salix lanata) приводится по сборам авторов 2004 г. с отвалов золотодобычи на руч. Олень, впадающем в Колымское водохранилище (окрестности бывшего пос. Сибик-Тыэллах, Тенькинский район).

В табл. 1 не включены виды, не обнаруженные нами, но приводимые в литературе. Так, только в окрестностях пос. Транспортный обнаружено 20 видов (Лысенко, 2006): Sparganium hyperboreum Laest. et Beurl., Poa sergievskajae Probat., P. nemoralis L., Elymus subfibrosus (Tzvel.) Tzvel., Eleocharis palustris (L.) Roem. et Schult., Carex minuta Franch, $C$. vesicata Meinsh., Polygonum neglectum Bess., Bistorta vivipara (L.) S. F. Gray, Chenopodium prostratum subsp. karoi (J. Murr) Lomonosova, Thalictrum contortum L., T. sparsiflorum Turcz. ex Fisch. et Mey., Thlaspi arvense L., Dimorphostemon pectinatus (DC.) Golubk., Dryas punctata Juz., Hedysarum dasycarpum Turcz., Lathyrus pilosus Cham., Callitriche palustris L., Artemisia commutata Bess., Carduus crispus L.

Только в Сусуманском районе обнаружено 66 видов (Беликович, 2001): Dryopteris fragrans (L.) Schott, Alopecurus alpinus Smith, Arctagrostis latifolia (R. Br.) Griseb., Agrostis trinii Turcz., Calamagrostis holmii Lange, C. neglecta (Ehrh.) Gaertn., Mey. et Scherb., Trisetum molle Kunth, Poa ochotensis Trin., P. pratensis L., Puccinellia distans (Jacq.) Parl., Festuca kolymensis Drob., Elymus confusus (Roshev.) Tzvel., E. jacutensis (Drob.) Tzvel., Carex appendiculata (Trautv. et C. A. Mey.) Kük., C. aquatilis Wahlenb., C. canescens L., C. cespitosa L., $C$. 
Таблища 1. Встречаемость видов растений, отмеченных авторами на отвалах золотодобычи изученных участков

Table 1. Frequency of plant species noted by the authors on gold-mining dumps of surveyed sites

\begin{tabular}{|c|c|c|c|c|c|}
\hline \multirow[b]{2}{*}{ Виды растений } & \multicolumn{5}{|c|}{ Участок сбора материала } \\
\hline & Омчак & $\begin{array}{c}\text { Тран- } \\
\text { спортный } \\
\text { (Лысенко, } \\
2006)\end{array}$ & Ягодное & $\begin{array}{c}\text { Родионов- } \\
\text { ский }\end{array}$ & $\begin{array}{c}\text { Сусу- } \\
\text { ман } \\
\text { (Бели- } \\
\text { кович, } \\
2001)\end{array}$ \\
\hline 1 & 2 & 3 & 4 & 5 & 6 \\
\hline Equisetum arvense L. & 3 & 3 & 2 & 1 & + \\
\hline E. fluviatile L. & 1 & 3 & 1 & & + \\
\hline E. pratense Ehrh. & 3 & 3 & - & - & - \\
\hline E. scirpoides Michx. & 1 & 1 & - & - & - \\
\hline Pinus pumila (Pall.) Regel & 3 & 2 & 2 & 3 & + \\
\hline Larix cajanderi Mayr & 3 & 3 & 3 & 2 & + \\
\hline Triglochin palustre L. & 2 & - & - & - & - \\
\hline Hierochloë annulata V. Petrov & 2 & 2 & - & - & - \\
\hline Alopecurus aequalis Sobol. & 1 & - & - & 1 & + \\
\hline Arctagrostis arundinacea (Trin.) Beal & 2 & - & - & - & + \\
\hline Agrostis anadyrensis Socz. & 2 & - & 1 & 2 & + \\
\hline A. clavata Trin. & 1 & - & - & - & - \\
\hline Calamagrostis langsdorffii (Link) Trin. & 3 & 4 & 3 & 3 & + \\
\hline C. lapponica (Wahlenb.) C. Hartm. & 1 & - & - & - & + \\
\hline Deschampsia sukatschevii (Popl.) Roshev. & 1 & - & - & 1 & + \\
\hline Trisetum spicatum (L.) K. Richt. & 1 & 1 & - & 1 & \\
\hline Beckmannia syzigachne (Steud.) Fern. & 1 & - & - & - & + \\
\hline Poa alpigena (Blytt) Lindm. & 2 & 1 & - & - & - \\
\hline P. botryoides (Trin. ex Griseb.) Kom. & 2 & - & - & - & - \\
\hline P. glauca Vahl & 3 & - & - & 1 & + \\
\hline P. palustris L. & 1 & - & - & - & - \\
\hline P. stepposa (Kryl.) Roshev. & 3 & 4 & - & - & - \\
\hline Puccinellia hauptiana V. Krecz. & 2 & 2 & 2 & - & + \\
\hline Festuca rubra L. & 1 & - & - & - & - \\
\hline Bromopsis pumpelliana (Scribn.) Holub & 1 & 2 & - & 1 & + \\
\hline *Elytrigia repens (L.) Nevski & 1 & 1 & - & 1 & - \\
\hline * Hordeum jubatum L. & 3 & 2 & 2 & 2 & + \\
\hline Elymus peschkovae Tzvel. & 1 & - & - & 1 & + \\
\hline E. kronokensis (Kom.) Tzvel. & 2 & - & - & - & + \\
\hline E. macrourus (Turcz.) Tzvel. & 1 & 1 & - & 1 & - \\
\hline *E. sibiricus L. & 1 & 2 & 1 & 1 & + \\
\hline Eriophorum russeolum Fries & 1 & 2 & 1 & - & + \\
\hline E. scheuchzeri Hoppe & 2 & - & - & - & - \\
\hline E. vaginatum L. & 1 & - & 1 & - & + \\
\hline Scirpus tabernaemontani C. C. Gmel. & 1 & - & - & - & - \\
\hline Carex eleusinoides Turcz. ex Kunth & 3 & 3 & 2 & - & + \\
\hline C. lapponica O. Lang & - & - & 1 & - & + \\
\hline C. lugens H. T. Holm & 1 & - & - & - & + \\
\hline C. pallida C. A. Mey. & 1 & 1 & 1 & - & + \\
\hline C. podocarpa R. Br. & 1 & - & - & - & - \\
\hline C. rhynchophysa C. A. Mey. & 1 & 1 & 1 & - & + \\
\hline Juncus alpinoarticulatus Chaix & 2 & 1 & - & - & \\
\hline J. castaneus Smith & 1 & 3 & - & - & + \\
\hline Luzula sp. & 1 & - & - & - & - \\
\hline Populus suaveolens Fisch. & 4 & 4 & 3 & 2 & + \\
\hline Chosenia arbutifolia (Pall.) A. Skvorts. & 4 & 4 & 1 & 3 & + \\
\hline
\end{tabular}


Продолжение табл. 1

\begin{tabular}{|c|c|c|c|c|c|}
\hline \multirow[b]{2}{*}{ Виды растений } & \multicolumn{5}{|c|}{ Участок сбора материала } \\
\hline & Омчак & $\begin{array}{c}\text { Тран- } \\
\text { спортный } \\
\text { (Лысенко, } \\
\text { 2006) }\end{array}$ & Ягодное & $\begin{array}{l}\text { Родионов- } \\
\text { ский }\end{array}$ & $\begin{array}{c}\text { Сусу- } \\
\text { ман } \\
\text { (Бели- } \\
\text { кович, } \\
2001 \text { ) }\end{array}$ \\
\hline 1 & 2 & 3 & 4 & 5 & 6 \\
\hline Salix abscondita Laksch. & 1 & 1 & - & - & - \\
\hline S. bebbiana Sarg. & 3 & 2 & 2 & 2 & + \\
\hline$\underline{\text { S. boganidensis Trautv. }}$ & 3 & 1 & 1 & 2 & + \\
\hline$\underline{\text { S. dshugdshurica A. Skvorts. }}$ & 3 & $(1)$ & 2 & 2 & $(+)$ \\
\hline S. hastata L. & 1 & 1 & - & 1 & - \\
\hline S. krylovii E. Wolf & - & - & - & 1 & + \\
\hline S. lanata L. & - & - & - & - & - \\
\hline S. pseudopentandra (B. Floder.) B. Floder. & 1 & 2 & - & 1 & + \\
\hline S. pulchra Cham. & 1 & - & - & - & + \\
\hline S. rorida Laksch. & 1 & 2 & - & - & + \\
\hline S. schwerinii E. Wolf & 4 & 4 & 3 & 4 & + \\
\hline S. udensis Trautv. et C. A. Mey. & 1 & 2 & 4 & 2 & + \\
\hline Betula middendorffii Trautv. et C. A. Mey. & 3 & 2 & 3 & 2 & + \\
\hline B. platyphylla Sukacz. & 1 & 1 & - & - & - \\
\hline Duschekia fruticosa (Rupr.) Pouzar & 3 & 2 & 3 & 3 & + \\
\hline Urtica angustifolia Fisch. ex Hornem. & 1 & 1 & - & - & - \\
\hline Rumex aquaticus L. & 2 & 2 & 2 & - & - \\
\hline Aconogonon ochreatum (L.) Hara & - & - & - & 1 & - \\
\hline A. tripterocarpum (A. Gray) Hara & - & - & 2 & - & + \\
\hline *Polygonum arenastrum Boreau & 1 & - & - & - & - \\
\hline P. humifusum Merk ex C. Koch & - & 2 & 1 & - & - \\
\hline *Chenopodium album L. & 1 & 1 & - & - & + \\
\hline Stellaria fischeriana Ser. & 1 & 1 & 1 & - & + \\
\hline$\underline{\text { S. longifolia Muehl. ex Willd. }}$ & 1 & 1 & 1 & 1 & + \\
\hline *S. media (L.) Vill. & 2 & 2 & 2 & - & - \\
\hline Moehringia lateriflora (L.) Fenzl & 1 & 2 & 2 & 1 & + \\
\hline Silene amoena $\mathrm{L}$. & 1 & - & - & 1 & + \\
\hline *Melandrium album (Mill.) Garcke & 1 & 1 & - & - & - \\
\hline Thacla natans (Pall. ex Georgi) Deyl et Soiak & - & 3 & 3 & - & + \\
\hline Pulsatilla dahurica (Fisch. ex DC.) Spreng. & 2 & - & 2 & - & + \\
\hline Ranunculus gmelinii DC. & 1 & 3 & 2 & - & + \\
\hline Ranunculus sceleratus L. & 1 & - & 2 & 1 & + \\
\hline Corydalis sibirica (L. fil.) Pers. & - & 1 & 1 & - & - \\
\hline Barbarea orthoceras Ledeb. & 1 & - & - & 1 & + \\
\hline Rorippa barbareifolia (DC.) Kitag. & 1 & 1 & 1 & 1 & + \\
\hline Draba hirta L. & - & - & 1 & - & + \\
\hline $\begin{array}{l}\text { *Descurainia sophioides (Fish. ex Hook.) O. E. } \\
\text { Schulz }\end{array}$ & 1 & 3 & - & 1 & + \\
\hline *Arabis pendula L. & 2 & 2 & 1 & 1 & - \\
\hline Erysimum cheiranthoides L. & 1 & 2 & - & - & - \\
\hline E. hieracifolium L. & 1 & 2 & - & - & + \\
\hline Saxifraga nelsoniana D. Don & - & - & - & 1 & + \\
\hline S. multiflora Ledeb. & 1 & - & - & 1 & + \\
\hline S. punctata L. & - & - & - & 4 & - \\
\hline Chrysosplenium alternifolium L. & 1 & - & - & - & + \\
\hline Parnassia palustris L. & 1 & 2 & - & - & - \\
\hline Ribes dikuscha Fisch. ex Turcz. & - & 1 & - & 1 & - \\
\hline R. triste Pall. & - & 1 & - & 1 & + \\
\hline
\end{tabular}


Продолжение табл. 1

\begin{tabular}{|c|c|c|c|c|c|}
\hline \multirow[b]{2}{*}{ Виды растений } & \multicolumn{5}{|c|}{ Участок сбора материала } \\
\hline & Омчак & $\begin{array}{c}\text { Тран- } \\
\text { спортный } \\
\text { (Лысенко, } \\
2006)\end{array}$ & Ягодное & $\begin{array}{l}\text { Родионов- } \\
\text { ский }\end{array}$ & $\begin{array}{c}\text { Сусу- } \\
\text { ман } \\
\text { (Бели- } \\
\text { кович, } \\
2001)\end{array}$ \\
\hline 1 & 2 & 3 & 4 & 5 & 6 \\
\hline Spiraea media Franz Schmidt & - & - & 1 & - & - \\
\hline S. betulifolia Pall. & - & - & - & 1 & - \\
\hline S. salicifolia $\mathrm{L}$. & 1 & 1 & 2 & - & - \\
\hline Rubus arcticus L. & 2 & 3 & 2 & - & + \\
\hline R. sachalinensis Lévl. & - & 1 & - & 1 & + \\
\hline Potentilla fruticosa $\mathrm{L}$. & 2 & 2 & - & - & + \\
\hline *Potentilla norvegica L. & 1 & 1 & 1 & 1 & + \\
\hline P. stipularis $\mathrm{L}$. & 1 & - & 1 & - & + \\
\hline *Geum aleppicum Jacq. & 1 & - & 2 & 1 & - \\
\hline Rosa acicularis Lindl. & 2 & 2 & 2 & 1 & + \\
\hline *Trifolium repens L. & 1 & - & - & - & - \\
\hline Astragalus alpinus L. & 3 & 3 & 2 & 1 & + \\
\hline A. frigidus (L.) A. Gray & - & - & 1 & - & - \\
\hline A. schelichovii Turcz. & 3 & 4 & 2 & 1 & + \\
\hline *Vicia cracca L. & 1 & - & - & - & - \\
\hline Chamaenerion angustifolium (L.) Scop. & 4 & 4 & 3 & 4 & + \\
\hline C. latifolium (L.) Th. Fries et Lange & 3 & 4 & 1 & 4 & + \\
\hline Epilobium davuricum Fisch. ex Hornem. & 2 & - & - & - & + \\
\hline Orthilia obtusata (Turcz.) Hara & 1 & 1 & - & - & - \\
\hline Pyrola rotundifolia $\mathrm{L}$. & - & 2 & 1 & - & + \\
\hline Ledum decumbens (Ait.) Lodd. ex Steud. & 1 & 1 & 1 & 1 & + \\
\hline Vaccinium uliginosum L. & 1 & 2 & 1 & 1 & + \\
\hline V. vitis-idaea $\mathrm{L}$. & 1 & 2 & 1 & 1 & + \\
\hline Androsace filiformis Retz. & - & - & 1 & 1 & + \\
\hline Comastoma tenellum (Rottb.) Toyokuni & 2 & - & - & - & + \\
\hline Gentianopsis barbata (Froehl.) Ma & 2 & - & - & - & - \\
\hline Lomatogonium rotatum (L.) Fries ex Fern. & 1 & - & - & - & - \\
\hline Polemonium boreale Adams & - & - & 1 & - & - \\
\hline *Linaria vulgaris Mill. & 1 & 1 & - & 1 & - \\
\hline Castilleja rubra (Drob.) Rebr. & 2 & 2 & 1 & 1 & + \\
\hline Euphrasia subpolaris Juz. & 1 & 2 & - & 1 & - \\
\hline Plantago depressa Willd. & 1 & 2 & - & 1 & - \\
\hline *P. major L. & 2 & 1 & - & - & - \\
\hline Galium boreale L. & 1 & 1 & 1 & - & - \\
\hline Erigeron politus Fries & 3 & 3 & 1 & 1 & + \\
\hline Antennaria dioica (L.) Gaertn. & - & - & 1 & 1 & - \\
\hline Achillea asiatica Serg. & 2 & 2 & - & 1 & - \\
\hline Ptarmica alpina (L.) DC. & 2 & - & 2 & & + \\
\hline *P. camtschatica (Rupr. ex Heimerl) Kom. & 2 & - & - & - & - \\
\hline *Lepidotheca suaveolens (Pursh) Nutt. & 2 & - & - & - & - \\
\hline Tanacetum boreale Fisch. ex DC. & 3 & 2 & 3 & 3 & + \\
\hline Artemisia arctica Less. & - & - & - & 1 & - \\
\hline A. borealis Pall. & 2 & 1 & 1 & 1 & - \\
\hline A. kruhsiana Bess. & 1 & - & 1 & - & + \\
\hline A. lagocephala (Bess.) DC. & - & - & - & 4 & - \\
\hline A. leucophylla (Turcz. ex Bess.) Clarke & 3 & 2 & 2 & 2 & $(+)$ \\
\hline A. tilesii Ledeb. & - & - & 2 & - & + \\
\hline *A. vulgaris $\mathrm{L}$. & 1 & - & - & - & + \\
\hline *Senecio vulgaris L. & 1 & 1 & 1 & 1 & - \\
\hline
\end{tabular}


Окончание табл. 1

\begin{tabular}{|c|c|c|c|c|c|}
\hline \multirow[b]{2}{*}{ Виды растений } & \multicolumn{5}{|c|}{ Участок сбора материала } \\
\hline & Омчак & $\begin{array}{l}\text { Тран- } \\
\text { спортный } \\
\text { (Лысенко, } \\
\text { 2006) }\end{array}$ & Ягодное & $\begin{array}{l}\text { Родионов- } \\
\text { ский }\end{array}$ & $\begin{array}{c}\text { Сусу- } \\
\text { ман } \\
\text { (Бели- } \\
\text { кович, } \\
2001)\end{array}$ \\
\hline 1 & 2 & 3 & 4 & 5 & 6 \\
\hline Taraxacum ceratophorum (Ledeb.) DC. & 2 & $(1)$ & 2 & 1 & + \\
\hline T. macroceras Dahlst. & 1 & 2 & 1 & - & - \\
\hline *Sonchus arvensis L. & - & - & 1 & - & - \\
\hline Mulgedium sibiricum Less. & 1 & - & - & - & - \\
\hline Crepis nana Richards. & 2 & 2 & 1 & 1 & + \\
\hline${ }^{*}$ C. tectorum L. & 3 & 3 & 2 & 3 & + \\
\hline $\begin{array}{l}\text { Уникальных видов (встречающихся только } \\
\text { в одном пункте) }\end{array}$ & $\begin{array}{c}16 \\
(13 \%)\end{array}$ & $\begin{array}{c}20 \\
(18 \%)\end{array}$ & $\begin{array}{c}5 \\
(7 \%) \\
\end{array}$ & $\begin{array}{c}5 \\
(7 \%) \\
\end{array}$ & $\begin{array}{c}66 \\
(42 \%) \\
\end{array}$ \\
\hline Адвентивных (всего 21 вид) & 18 & 17 & 9 & 7 & 13 \\
\hline $\begin{array}{l}\text { Всего видов, с учетом приведенных ниже } \\
\text { в тексте из списков А. В. Беликович (2001) } \\
\text { и Д. С. Лысенко (2006) }\end{array}$ & 123 & 114 & 73 & 69 & 158 \\
\hline
\end{tabular}

Примечания:

1. Цифрами от 1 до 4 обозначена частота встречаемости вида: 1 - встречен один - несколько экземпляров вида в одной точке; 2 - вид встречался неоднократно, но в числе одной - нескольких особей; 3 - вид встречается достаточно часто и представлен большим количеством особей; 4 - обычный вид.

2. Присутствие вида в окрестностях г. Сусуман отмечено знаком «+» из-за отсутствия данных по частоте встречаемости. В скобки взята встречаемость 3 видов, не отмеченных А. В. Беликович (2001) и Д. С. Лысенко (2006), но обычных в данном районе, и их присутствие на отвалах весьма вероятно (пояснения к конкретным видам приводятся в тексте ниже).

3. Звездочкой обозначены адвентивные виды.

Таблица 2. Количественная характеристика 10 ведущих семейств сосудистых растений на обследованных участках отвалов золотодобычи в Магаданской области

Table 2. Quantitative characteristics of $\mathbf{1 0}$ leading vascular plant families at the surveyed sites of gold mining dumps in Magadan Oblast

\begin{tabular}{|l|l|c|c|c|c|}
\hline $\begin{array}{c}\text { № } \\
\text { п/п }\end{array}$ & \multicolumn{1}{|c|}{ Семейство } & Общий список & Омчак & Транспортный & Сусуман \\
\hline 1 & Poaceae & $38(16 \%)$ & $24(20 \%)$ & $14(12 \%)$ & $27(17 \%)$ \\
\hline 2 & Asteraceae & $29(12 \%)$ & $16(13 \%)$ & $12(11 \%)$ & $16(10 \%)$ \\
\hline 3 & Cyperaceae & $22(9 \%)$ & $9(7 \%)$ & $7(6 \%)$ & $14(9 \%)$ \\
\hline 4 & Salicaceae & $16(7 \%)$ & $12(10 \%)$ & $12(11 \%)$ & $12(8 \%)$ \\
\hline 5 & Brassicaceae & $16(7 \%)$ & $6(5 \%)$ & $9(8 \%)$ & $12(8 \%)$ \\
\hline 6 & Rosaceae & $13(5,4 \%)$ & $7(5 \%)$ & $7(6 \%)$ & $8(5 \%)$ \\
\hline 7 & Caryophyllaceae & $11(5 \%)$ & $6(5 \%)$ & $5(4 \%)$ & $9(6 \%)$ \\
\hline 8 & Fabaceae & $11(5 \%)$ & $4(3 \%)$ & $4(3,5 \%)$ & $6(4 \%)$ \\
\hline 9 & Ranunculaceae & $10(4 \%)$ & $3(2 \%)$ & $4(3,5 \%)$ & $8(5 \%)$ \\
\hline 10 & Scrophulariaceae & $8(3 \%)$ & $3(2 \%)$ & $3(3 \%)$ & $6(4 \%)$ \\
\hline \multicolumn{2}{|r|}{ Всего } & $174(72 \%)$ & $90(73 \%)$ & $77(68 \%)$ & $118(75 \%)$ \\
\hline
\end{tabular}

drymophila Turcz. ex Steud., C. globularis L., C. juncella (Fries) Th. Fries, C. media R. Br., C. saxatilis L., Juncus bufonius L., Luzula confusa Lindeb., L. multiflora (Ehrh. ex Retz.) Lej. s. 1., L. rufescens Fish. ex E. Mey., Salix pyrolifolia Ledeb., Polygonum aviculare L., Stellaria angarae M. Pop., S. dahurica Willd. ex Schlecht., Gastrolychnis taimyrensis (Tolm.) Czer., Gypsophila violacea (Ledeb.) Fenzl, Caltha palustris L. s.1., Ranunculus affinus R. Br., R. turneri Greene, Thalictrum foetidum L., Papaver lapponicum (Tolm.) Nordh., Corydalis arctica M. Pop., Eutrema edwardii R. Br., Rorippa palustris (L.) Bess., Draba cinerea Ad- ams, Arabis hirsuta (L.) Scop., A. turczaninowii Ledeb., Potentilla asperrima Turcz., P. inquinans Turcz., Astragalus inopinatus Boriss., Oxytropis vasskovskyi Jurtz., Hedysarum hedysaroides (L.) Schinz et Thell., Vicia multicaulis Ledeb., Epilobium palustre L., Andromeda polifolia L., Androsace septentrionalis L., Polemonium villosum Rudolph ex Georgi, Limosella aquatica L., Pedicularis labradorica Wirsing, P. lapponica L., P. sceptrum-carolinum L., P. sudetica Willd., Valeriana capitata Pall. ex Link, Campanula turczaninovii Fed., Erigeron acris L., E. kamtschaticus DC., Endocellion sibiricum (J. F. Gmel.) Toman, Petasites frigidus (L.) 
Fries, Tephroseris palustris (L.) Reichenb., Taraxacum lateritium Dahlst., Crepis gmelinii (L.) Tausch.

В окрестностях и г. Сусуман, и пос. Транспортный встречаются 6 видов: Salix saxatilis Turcz. ex Ledeb., Betula exilis Sukacz., Draba nemorosa L., Descurainia sophia (L.) Webb ex Prantl, Hippurus vulgaris L., Lappula squarrosa (Retz.) Dumort (Беликович, 2001; Лысенко, 2006).

Данные списки несколько отличаются от приводимых авторами, так как часть видов в настоящее время сведена в синонимы, некоторые, по нашему мнению, были пропущены при обследовании, а 3 вида отсутствуют на территории области. Комментарии к каждому виду приводятся в обсуждении.

В табл. 2 показано количество видов в 10 ведущих семействах флоры отвалов золотодобычи Магаданской области.

\section{ОБСУЖДЕНИЕ РЕЗУЛЬТАТОВ} бычи

Ведущие семейства флоры отвалов золотодо-

Всего для Колымского флористического района Магаданской области, включающего все участки наших работ, известно более 1000 видов (Флора..., 2010). В пределах района изучены 4 конкретные флоры. Наиболее богатой и хорошо изученной является флора Оротукского стационара, расположенного на расстоянии менее 100 км от всех изученных участков (см. рисунок). Флора окрестностей Оротукского стационара включает 506 видов, окрестностей стационара «Контакт», расположенного в 13 км от пос. Кулу - 321 вид, стационара «Абориген», расположенного возле пос. Сибик-Тыэллах - 237 видов (Синельникова, 2009), окрестностей г. Сусуман - 365 видов (Беликович, 2001).

При сравнении видового богатства различных семейств мы видим, что во флорах всех участков лидируют семейства Pоасеае и Asteraceae. Семейство Суреraceae находится на 3-4-м месте (см. табл. 2). Такой состав 3 ведущих семейств характерен для большинства бореальных флор (Малышев, 1972; Толмачев, 1986).

Наибольшее сходство спектра ведущих семейств флоры отвалов золотодобычи наблюдается с флорой окрестностей Оротукского стационара (Синельникова, 2009). Расположение первых 4 семейств одинаково в общем списке флоры отвалов и в списке Н. В. Синельниковой. Семейство Salicaceae, по нашим данным, выдвигается на 4-е место в общем списке, во флоре отдельных участков на 2-е, 3-е и 4-е места. В большинстве бореальных флор это семейство находится в конце списка из 10 ведущих семейств или вообще в него не входит. Вероятно, высокая доля видов семейства Salicaceae на отвалах золотодобычи отражает роль этого семейства во флоре верховьев Колымы. Кроме того, большинство видов ив - растения пойменных галечников, условия произрастания на которых близки к условиям отвалов россыпной золотодобычи.

В списке ведущих семейств Н. В. Синельниковой отсутствуют семейства Fabaceae и Scrophulariaceae, на 9-м и 10-м месте - семейства Saxifragaceae и Ericaceae, роль которых во флоре отвалов незначительна.

В спектре семейств синантропной флоры Магаданской области (Лысенко, 2012) на 3-м месте указывается семейство Rosaceae, на 4-м - Fabaceae, на 6-м месте - Polygonaceae (в нашем случае 12-е место) и на 10-м месте отсутствующее на отвалах семейство Apiaceae. Семейство Cyperaceae в синантропной флоре отодвигается на 7-е место, в то время как в большинстве природных бореальных флор оно находится на 2 - 4-м месте.

Таким образом, список 10 ведущих семейств флоры отвалов золотодобычи Магаданской области в общих чертах совпадает с таковым для бореальных флор.

\section{Сравнение флористических списков}

Наиболее близко друг к другу (на расстоянии 12 км) расположены участки в окрестностях пос. Омчак и пос. Транспортный. Оба они находятся на полностью нарушенной части долины р. Омчак.

Отдельные виды фигурируют в двух списках для долины р. Омчак под разными названиями. Так, Ledum decumbens ошибочно приводится Д. С. Лысенко (2006) как L. palustre L. В окрестностях пос. Транспортный отмечен 1 вид одуванчика - Taraxacum macroceras, а в окрестностях пос. Омчак - T. ceratophorum и T. macroceras. Это два близких по морфологии и экологии вида. Позднее Д. С. Лысенко (Флора..., 2010) указывает оба вида как сообитающие на отвалах, а T. ceratophorum - как более обычный в антропогенных местообитаниях в районе верховьев р. Колыма. Вероятно, оба вида произрастают на отвалах золотодобычи Тенькинского района, но из окрестностей пос. Транспортный в гербарий были собраны только экземпляры T. macroceras. В списке Д. С. Лысенко нет Salix dshugdshurica. По нашим данным, этот вид обычен в Тенькинском районе, в том числе и на отвалах золотодобычи. Вероятно, он не был отделен от близкого вида $S$. boganidensis. Приводимый для этого же участка Juncus nodulosus Wahlenb. отсутствует в Магаданской области (Флора..., 2010). Возможно, это неверно определенный $J$. alpinoarticulatus. Bce перечисленные виды приняты нами как общие для обоих списков, всего для долины р. Омчак отмечено 156 видов. Общим для всех отвалов в долине р. Омчак является 81 вид (52\%).

А. В. Беликович (2001) указывает 156 видов для отвалов Сусуманского района. В публикации нет отдельного списка этих видов, но есть информация по встречаемости растений в различ- 
ных сообществах. На основании этих данных мы выделили список видов для отвалов, оставленных под самозарастание, в нем 163 вида.

Некоторые виды из приводимых А. В. Беликович в настоящее время сведены в синонимы. Так, Elymus scandicus (Nevski) A. Khokhr. и E. neoborealis A. Khokhr. - синонимы $E$. kronokensis, Poa anadyrica Roshev. - синоним P. glauca, Epilobium tundrarum Sam. - синоним E. davuricum. Chenopodium viride L. - синоним C. album. Все сборы А. В. Беликович в гербарии ИБПС ДВО РАН, определенные ранее как Chenopodium vachelii Hook. et Arn., относятся к C. album. Stellaria dahurica Willd. ex Schlecht. и Vicia multicaulis Ledeb., по современным данным, отсутствуют в Магаданской области, в гербарии ИБПС ДВО РАН этих видов нет. Последние 2 вида мы учитывали в общем списке, имея в виду, что это, вероятно, неправильно определенные другие виды этих родов.

Исходя из современного систематического положения видов, на отвалах золотодобычи по данным А. В. Беликович отмечено 158 видов сосудистых растений. Из них 86 видов встречаются в наших списках, еще 6 видов - в списке Д. С. Лысенко, 66 видов отмечены только А. В. Беликович.

Высокая доля уникальных для каждого участка видов (7-42\%) и большое различие между списками близких участков в долине р. Омчак (52\% общих видов) говорит о значительной роли случайного заноса зачатков растений в формировании флоры отвалов золотодобычи. Больше всего уникальных видов отмечено в окрестностях г. Сусуман. Это отчасти объясняется большой площадью обследования и присутствием ксерофитных видов, занесенных с сухих приречных склонов. Таких местообитаний нет в окрестностях остальных изученных участков.

Сходная картина наблюдалась на карьерах для добычи щебня на Чукотке (Сумина, Яцкевич, 1990), где состав флоры на отдельных карьерах сильно отличается.

Редкие виды растений во флоре отвалов

Нами в окрестностях пос. Омчак отмечено произрастание Scirpus tabernaemontani в водоеме, занимающем дражную пазуху. В Магаданской области этот южный вид крайне редок, вторая его находка - в окрестностях пос. Оротук (Синельникова, 2002), где он также произрастал в искусственном водоеме на отвалах золотодобычи. Вероятно, возможность выживания этого вида на отвалах обеспечивается повышенной теплообеспеченностью данных местообитаний по сравнению с естественными (Жавнерова и др., 1983).

Для отвалов Сусуманского района приводится Salix pyrolifolia (Беликович, 2001). Этот вид, занесенный в Красную книгу Магаданской области (Красная..., 2019), в природе встречается только вблизи мест выходов кальцийсодержащих по- род. Также в списке присутствует эндемик верховий р. Колыма Oxytropis vasskovskyi. Популяции O. vasskovskyi отмечались на отвалах золотодобычи в Сусуманском районе в 2017 г. (Селютина и др., 2018). В окрестностях пос. Транспортный отмечен редкий кальцефильный вид Hedysarum dasycarpum (Лысенко, 2006).

Эти данные говорят о том, что возможно выживание некоторых редких видов на начальных стадиях посттехногенных сукцессий.

Наиболее обычные виды отвалов золотодобычи

Во всех или почти во всех описаниях встречаются 44 вида растений, в табл. 1 их названия подчеркнуты. 9 из них не отмечены на руч. Родионовский. Вероятно, 5 из этих видов (Equisetum fluviatile, Eriophorum russeolum, Carex eleusinoides, C. rhynchophysa, Ranunculus gmelinii) отсутствуют, так как нет необходимых им влажных местообитаний. Остальные виды (Stellaria fischeriana, S. media, Rubus arcticus, Puccinellia hauptiana) могли быть пропущены при обследовании. В окрестностях пос. Транспортный не приводятся Salix dshugdshurica и Taraxaccum ceratophorum (см. комментарии к этим видам выше). В окрестностях г. Сусуман не отмечены 4 из широко распространенных на отвалах видов: Arabis pendula, Artemisia leucophylla, Salix dshugdshurica, Stellaria media. Возможно, Artemisia leucophylla и субтильные растения Arabis pendula могли быть неверно определены как другие виды этих родов - Artemisia vulgaris и Arabis turczaninowii или A. hirsuta. Salix dshugdshurica, скорее всего, была определена как Salix boganidensis, как и многие образцы этого вида, хранящиеся в гербарии ИБПС. Stellaria media обычна на всех обследованных нами участках, поэтому включена в список. Poa stepposa отмечен только в долине р. Омчак, но там это один из 2 наиболее обильных видов из семейства Роасеае наряду с Calamagrostis langsdorffi (см. табл. 1).

Большинство обычных на отвалах золотодобычи видов можно отнести к доминантам формирующихся растительных сообществ. Это все древесные растения, в первую очередь виды семейства Salicaceae. Из травянистых растений часто доминируют Calamagrostis langsdorffi, Poa stepposa, Hordeum jubatum, Chamaenerion angustifolium, Crepis tectorum. Некоторые виды с невысокой встречаемостью (Potentilla norvegica, Rorippa barbareifolia, Stellaria fischeriana, $S$. longifolia) ведут себя так же и в других местообитаниях.

Во флоре отвалов отмечен 21 адвентивный вид растений, из них всего 4 относятся к обычным на отвалах видам (Hordeum jubatum, Arabis pendula, Potentilla norvegica, Crepis tectorum). Только Hordeum jubatum и Crepis tectorum изредка выступают доминантами в сообществах травянистых растений. 
Рассмотрим экологическую приуроченность обычных на отвалах видов.

Ивы (Salix) растут в разнообразных местообитаниях, но чаще около стоячих водоемов (кроме Salix bebbiana), у подножия склонов насыпных холмов и вдоль края долины. На выровненных отвалах в долинах рек нередко образуют сомкнутые сообщества с густым травостоем. Возле водотоков на отвалах золотодобычи ивы, как и остальные древесные растения, как правило, отсутствуют, вероятно, из-за неустойчивости русла.

Populus suaveolens и Chosenia arbutifolia pacтут вдоль крупных водотоков, а также на склонах и вершинах насыпных холмов. Эти виды чаще других встречаются на крупногалечных отвалах.

Pinus pumila и Larix cajanderii предпочитают мелкобугристый микрорельеф с буграми высотой до 3-4 м, сложенными грунтом, содержащим мелкие фракции.

Duschekia fruticosa чаще всего встречается на заброшенных дорогах и разведочных ходах на крутых склонах сопок, где образует сомкнутые монодоминантные сообщества со слабым участием травянистых видов. На отвалах вскрыши обычны отдельные растения D. fruticosa в составе различных сообществ.

Ledum decumbens, Vaccinium uliginosum, $V$. vitis-idaea произрастают преимущественно на отвалах, в состав которых входит снятый слой почвы. Calamagrostis langsdorffi, Rosa acicularis, Rubus arcticus отмечались в разнообразных местообитаниях, но наиболее обильны на отвалах, содержащих почву и мелкозем.

Equisetum arvense, E. fluviatile, Eriophorum russeolum, Ranunculus gmelinii, Rorippa barbareifolia растут во влажных местообитаниях возле водоемов и водотоков, на спущенных илоотстойниках, всегда на грунте, содержащем мелкие частицы - песок, ил.

На первых стадиях зарастания незадернованные каменистые россыпи наиболее активно заселяют Poa stepposa, Astragalus schelichovii, Stellaria fischeriana, S. longifolia, Artemisia leucophylla, Erigeron politus, Crepis tectorum, Taraxacum ceratophorum.

Stellaria media и Moehringia lateriflora встречаются в сомкнутых растительных сообществах, преимущественно в ивняках.

Остальные виды не имеют выраженной экологической приуроченности и встречаются в разнообразных местообитаниях.

Мы считаем, что большинство обычных на отвалах 44 видов могут использоваться при рекультивации отвалов золотодобычи. На практике нужно учитывать многие факторы - наличие естественного заноса зачатков растений, возможность сбора в природе или покупки семян, особенности прорастания семян.

\section{ЗАКЛЮЧЕНИЕ}

На обследованных нами отвалах россыпной золотодобычи отмечено 148 видов сосудистых растений. Общий список сосудистых растений, произрастающих на отвалах золотодобычи Магаданской области, по оригинальным и литературным данным, включает 241 вид. Отмечены значительные различия во флоре различных участков нарушенных территорий (до 48\% для расположенных всего в 12 км участков в долине р. Омчак). Список ведущих 10 семейств соответствует зональному положению района работ в Бореальной флористической области.

Состав флоры отвалов золотодобычи изменяется как в зависимости от расположенных рядом растительных сообществ, так и от случайного антропохорного заноса семян синантропных растений.

На отвалах могут произрастать редкие и эндемичные виды растений. Так, Scirpus tabernaemontani в Магаданской области произрастает только в искусственных водоемах на отвалах золотодобычи.

Выделены 44 вида, нередкие или обильные практически на всех изученных участках, многие из них могут быть рекомендованы для рекультивации отвалов золотодобычи в Магаданской области.

Работа выполнена в рамках плановой темы НИР лаборатории ботаники ИБПС ДВО РАН АААА-А17117122590002-0.

\section{ЛИТЕРАТУРА}

Андреев А. В. Эталоны природы Охотско-Колымского края. Магадан : СВНЦ ДВО РАН, 2013. 322 с.

Беликович A. В. Растительный покров Сусуманского района Магаданской области // Комаровские чтения. 2001. Вып. 48. С. 125-154.

Борисова И. Г., Старченко В. М. Проблемы рекультивации нарушенных территорий // Вестник СевероВосточного научного центра ДВО РАН. 2009. № 3. C. 54-63.

Жавнерова М. А., Замощ М. Н., Папернов И. М. Некоторые результаты исследований агроклиматической азональности рекультивированных земель // Биологические проблемы Севера : тез. 10-го Всесоюз. симп. Магадан : ИБПС ДВО РАН, 1983. Ч. 1. С. 283-284.

Замош М. Н. Рекультивация нарушенных земель горнорудных районов Северо-Востока России (история, реальность, перспективы) // Проблемы освоения техногенного комплекса месторождений золота : Материалы межрегион. конф. (Магадан, 15-17 июля 2010 г.). Магадан : СВКНИИ ДВО РАН, 2010. С. 92103.

Захарова В. И., Карпов Н. С., Перфильева В. И. Флора и растительность природных и техногенных ландшафтов // Влияние горнодобывающей промышленности на экосистемы Северо-Востока Якутии. Новосибирск : Наука, 2010. 208 с.

Ивакина Е. В., Осипов С. В. Естественное и искусственное лесовосстановление в горнопромышленных ландшафтах Дальнего Востока России // Сибирский 
лесной журнал. 2016. № 2. С. 6-21. DOI: 10.15372/ SJFS20160201

Ивакина Е. В., Якубов В. В., Осипов С. В. Сосудистые растения участка угледобычи «Лузановский» (российский Дальний Восток) // Сибирский экологический журнал. 2013. № 2. С. 234-247.

Капелькина Л. П., Сумина О. И., Лавриненко И. А., Лавриненко О. В., Тихменев Е. А., Миронова С. И. Самозарастание нарушенных земель Севера. СанктПетербург : Изд-во ВВМ, 2014. 204 с.

Красная книга Магаданской области. Редкие и находящиеся под угрозой исчезновения виды животных, растений и грибов. Магадан : Охотник, 2019. 356 с.

Лысенко Д. С. Сосудистые растения дражных отвалов в слиянии рр. Омчак и Тенке (Магаданская область) // Геология, география и биологическое разнообразие Северо-Востока России : Материалы Дальневост. регион. конф., посвящ. памяти А. П. Васьковского и в честь его 95-летия (Магадан, 28-30 ноября 2006 г.). Магадан : СВНЦ ДВО РАН, 2006. С. 378-383.

Льсенко Д. С. Синантропная флора Магаданской области. Магадан : СВНЦ ДВО РАН, 2012. 111 с.

Мальшев Л. И. Флористические спектры Советского Союза // История флоры и растительности Евразии. Ленинград : Наука, 1972. С. 17-40.

Миркин Б. М., Наумова Л. Г., Соломещ, А. И. Современная наука о растительности : учебник. Москва : Логос, 2001. 264 с.

Миронова С. И. Растительные сукцессии на природно-техногенных ландшафтах Западной Якутии и их оптимизация. Москва : Издат. Дом «Академия Естествознания», 2016. 140 с.

Осипов С. В., Черданцева В. Я., Галанина И. А., Якубов $B$. В. Видовой состав и эколого-ценотические спектры сосудистых растений, мхов и лишайников на участках золотодобычи в таежной зоне Нижнего Приамурья (Дальний Восток) // Сибирский экологический журнал. 2008. № 4. С. 553-569.

Подковыркина H. E. Особенности зарастания вскрышных пород техногенного рельефа Верхней Колымы // Резервы повышения эффективности земледелия на Крайнем Северо-Востоке : науч. техн. бюл. Новосибирск, 1989. Вып. 1/2. С. 87-88.
Поспелова Е. Б., Тииков А. А. К вопросу о флоре зарастающих нарушенных участков долины реки Берелех (Магаданская область) // Почвы и растительность мерзлотных районов СССР : тез. докл. V симпоз. «Биологические проблемы Севера». Магадан : Обл. типография, 1973. С. 25-32.

Пугачев А. А., Тихменев Е. А. Восстановление горнопромышленных ландшафтов Северо-Востока России // Вестник Северо-Восточного научного центра ДВО РАН. 2007. № 2. С. 72-82.

Селютина В. Ю., Санданов Д. В., Синельникова H. B., Андриянова E. A. Демографическая структура популяций некоторых видов Oxytropis L. (Fabaceae) Северо-Восточной Азии // Биологические проблемы Севера : Материалы междунар. науч. конф., посвящ. памяти акад. В. Л. Контримавичуса (Магадан, 1822 сент., 2018 г.). Магадан, 2018. С. 131-133.

Синельникова Н. В. О находке Scirpus tabermontanii (Суperaceae) в Магаданской области // Ботанический журнал. 2002. Т. 78, № 6. С. 130-131.

Синельникова Н. В. Эколого-флористическая классификация растительных сообществ верховий Колымы. Магадан : СВНЦ ДВО РАН, 2009. 214 с.

Сумина О. И., Яикевич В. В. Цветковые на техногенных местообитаниях Чукотки (на примере карьеров щебня) // Вестник ЛГУ. 1990. Сер. 3. Вып. 3. № 17. C. 41-45.

Tихменев $E$. A. Семенная репродукция и особенности формирования растительных сообществ СевероВостока Азии // Известия Самарского научного центра РАН. 2010. Т. 12, № 1 (3). С. 827-831.

Тихменев Е. А., Тихменев П. Е. Технологические аспекты противоэрозионной рекультивации золоторудных месторождений криолитозоны // Там же. 2012. T. 14, № 1 (3). С. 817-821.

Толмачев А. И. Методы сравнительной флористики и проблемы флорогенеза. Новосибирск : Наука, 1986. 195 c.

Флора и растительность Магаданской области (конспект сосудистых растений и очерк растительности). Магадан : ИБПС ДВО РАН, 2010. 364 с.

Юриев Б. А. Проблемы ботанической географии Северо-Восточной Азии. Ленинград : Наука, 1974. 160 с.

Поступила в редакиию 17.07.2020 2.

Поступила после доработки 19.08.2020 г.

\title{
VASCULAR PLANTS OF GOLD MINING DUMPS IN MAGADAN OBLAST
}

\author{
E. A. Andriyanova, V. B. Dokuchaeva
}

\author{
Institute of the Biological Problems of the North, FEB RAS, Magadan
}

\begin{abstract}
The list of vascular plants found to date in the areas disturbed by gold mining in the continental part of Magadan Oblast has been compiled according to the original and published data. In total, 241 species of vascular plants grow at the gold-mining dumps in Tenkinsky, Yagodninsky and Susumansky districts. The range of leading families in flora of technogenic landscapes is characteristic for boreal flora. Some endemic (Oxytropis vasskovskyi) and rare (Scirpus tabernaemontani, Salix pyrolifolia) species grow in the dumps. We identified 44 plant species that can be used for gold mining dumps recultivation in Magadan Oblast.
\end{abstract}

Keywords: flora, disturbed teritories, natural revegetation, Magadan Oblast. 


\section{REFERENCES}

Andreev, A. V., 2013. Nature Paragons of the OkhotskKolyma Country. Magadan, NESC FEB RAS [In Russian].

Belikovich, A. V., 2001. The Vegetation Cover of Susumanskiy District of Magadan Oblast, Komarovskiye Chteniya. 48, 125-154 [In Russian].

Borisova, I. G., Starchenko, V. M., 2009. Problems of Disturbed Lands Recultvation, Bulletin of the NESC FEB RAS. 3, 54-63 [In Russian].

Flora and Vegetation of Magadan Oblast (Checklist of Vascular Plants and Outline of Vegetation), 2010. Magadan, IBPN FEB RAS [In Russian].

Ivakina, E. V., Osipov, S. V., 2016. Natural and Artificial Reforestation in the Mining Landscapes of the Russian Far-East, Siberian Journal of Forest Science. 2, 6-21 [In Russian].

Ivakina, E. V., Yakubov, V. V., Osipov, S. V., 2013. Vascular Plants of the Luzanovskiy Coal-Mining Site (Russia's Far-East), Contemporary Problems of Ecology. 6, 187-198. DOI: 10.1134/S1995425513020054 [In Russian].

Kapelkina, L. P., Sumina, O. I., Lavrinenko, I. A., Lavrinenko, O. V., Tikhmenev, E. A., Mironova, S. I., 2014. Natural Revegetation on Disturbed Lands of the North. St. Petersburg, VVM Publishing [In Russian].

Lysenko, D. S., 2006. Vascular Plants of Dredge Rejected Excavations in the Junction of the Omchak and Tenke Rivers (Magadan Region), Geology, Geography and Biologic Diversity of Northeastern Russia: Proceedings of the Far East Regional Conference Dedicated to the Memory of A. P. Vaskovsky and his 95th Birth Anniversary (Magadan, November 28-30, 2006). Magadan, NESC FEB RAS. 378-383 [In Russian].

Lysenko, D. S., 2012. Sinantropic Flora of Magadan Oblast. Magadan, NESC FEB RAS [In Russian].

Malyshev, L. I., 1972. The Floristic Spectra of the Soviet Union, History of Flora and Vegetation in Eurasia. Leningrad, Nauka. 17-40 [In Russian].

Mirkin, B. M., Naumova, L. G., Solomeshch, A. I., 2001. The Modern Science on Vegetation. Textbook. Moscow, Logos [In Russian].

Mironova, S. I., 2016. Plant Successions in Natural and Man-Made Landscapes of Western Yakutia and Their Optimization. Moscow [In Russian].

Osipov, S. V., Cherdantseva, V. Ya., Galanina, I. A., Yakubov, V. V., 2008. Species Composition and Ecologo-Phytocenotic Spectra of Vascular Plants, Mosses, and Lichens on Gold-Mining Sites in the Taiga Zone of the Lower Amur River Basin, Russia's Far-East, Contemporary Problems of Ecology. 1, 4, 425-439. DOI 10.1134/ S1995425508040061 [In Russian].

Podkovyrkina, N. E., 1989. Features of Overburden Rocks Overgrowing in the Technogenic Relief of the Upper Kolyma, Reserves of Increasing the Efficiency of Farming in the Far North-East: Scientific and Technical Bulletin. 1/2. Novosibirsk. 87-88 [In Russian].
Pospelova, E. B., Tishkov, A. A., 1973. On the Flora of Overgrowning Infringed Sites of the Valley of the Berelyokh river, Soil and Vegetation of Permafrost Regions of the USSR, Abstracts of the "Biological Problems of the North” Symposium. Magadan, 25-32 [In Russian].

Pugachev, A. A., Tikhmenev, E. A., 2007. Restoration of Post-Mining Landscapes in the North-East of Russia, Bulletin of the NESC FEB RAS. 2, 72-82 [In Russian].

Red Book of Magadan Oblast, Rare and Endangered Species of Animals, Plants and Fungi, 2019. Magadan, Okhotnik [In Russian].

Selyutina, I. Yu., Sandanov, D. V., Sinel'nikova, N. V., Andriyanova, E. A., 2018. Demographic Structure of Some Oxytropis L. (Fabaceae) Species Populations in Northeast Asia, Biological Problems of the North : The Materials of International Scientific Conference, Dedicated to Academician V. L. Kontrimavichus (Magadan, September, 18-22 2018). Magadan, IBPN FEB RAS. 131133 [In Russian].

Sinelnikova, N. V., 2002. On Finding Scirpus Tabermontanii (Cyperaceae) in Magadan Oblast, Botanicheskii Zhurnal. 78, 6, 130-131 [In Russian].

Sinelnikova, N. V., 2009. Classification of Plant Communities of the Upper Kolyma Region (North-East Russia). Magadan, NESC FEB RAS [In Russian].

Sumina, O. I., Yatsckevich V. V., 1990. Flowering Plans in Anthropogenic Habitats of Chukotka, Bulletin of Leningrad State University. Ser. 3, 3 (17), 41-45 [In Russian].

Tikhmenev, E. A., 2010. Seed Reproduction and Features of Formation the Vegetative Communities in the North-East of Asia, Isvestia of Samara Scientific Center RAS. 12, 1 (3), 827-831 [In Russian].

Tikhmenev, E. A., Tikhmenev, P. E., 2012, Technological Aspects of the Antierosion Revegation of Ore Gold Deposits of Cryolitozone, Ibid. 14, 1 (3), 817-821 [In Russian].

Tolmachev, A. I., 1986. Methods of Comparative Floristics and the Problems of Florogenesis. Novosibirsk, Nauka [In Russian].

Yurtzev B. A., 1974. Problems of Phytogeography of Northeast Asia. Leningrad, Nauka [In Russian].

Zakharova, V. I., Karpov, N. S., Perfileva, V. I., 2010. Flora and Vegetation of Natural and Technogenic Landscapes, Impact of Mining Ecosystems in the Northeast of Yakutia. Novosibirsk, Nauka [In Russian].

Zamosch, M. N., 2010. Gold Mining Dumps Recultivation Mining Dumps of Russian North-East (History, Reality, Perspectives), Problems of Development of the Technogenic Complex of Gold Deposits : Proceedings of the Interregional Conference (Magadan, July 15-17, 2010). 92-103 [In Russian].

Zhavnerova, M. A., Zamosch, M. N., Papernov, I. M., 1983. Some Results of Studying Climatic Azonality of Disturbed Lands. Biological Problems of the North. Symposium Proceeding. Magadan, IBPN FEB RAS. 1, 283284 [In Russian]. 